\title{
Pelatihan Protokol Kesehatan Bagi Pemandu Wisata Pedesaan Di Kabupaten Belitung
}

\author{
Rina Fitriana*1, Wisnu Bawa Tarunajaya ${ }^{2}$, Kemal Akbar \\ 1,Politeknik Sahid \\ ${ }^{2,3}$ Kementerian Pariwisata dan Ekonomi Kreatif, Republik Indonesia \\ *e-mail: rinafitriana@polteksahid.ac.id ${ }^{1}$
}

\begin{abstract}
Facing the era of new habit adaptation, Belitung Regency Tourism Office again held training for rural tourism guides and tourist village managers aimed at preparing them to market tourist villages and provide excellent service guarantees in accordance with the health protocol as arranged by the government. One of the materials provided in the training is about health protocol in tourist destination and its practice. 40 trainees joined the training that was delivered using presentation, tutorial, discussions and practices. The results of the training showed 70\% (28 participants) stated that it was their first training on health protocol, $90 \%$ (36 participants) believed that the theory could be applied in their tourist village while 10\% (4 participants) stated there were various supporting facilities that still had to be equipped in order for the tour activities to run in accordance with existing health protocols. As many as 60\%participants (24 people) stated that for the sake of deepening the material, duration of the training needs to be extended, while 50\% participants (20 people) believed that it would be better if in the next training, health workers are presented so that the preparation of Operational Standards Procedures (SOP) for tourist villages, such as SOP in tourist attractions and homestays, can be done as one of the training outputs that can help the participants when they want to apply it in their destinations.
\end{abstract}

Keywords: Era of New Habit Adaptation, Health Protocol, Rural Tourism Guide,

\begin{abstract}
Abstrak
Menghadapi era adaptasi kebiasaan baru, Dinas Pariwisata Kabupaten Belitung kembali mengadakan pelatihan bagi pramuwisata pedesaan dan pengelola Desa Wisata yang bertujuan menyiapkan pelaku wisata agar mampu memasarkan Desa Wisata dan memberikan jaminan pelayanan prima yang sesuai dengan protokol kesehatan yang ditetapkan pemerintah. Salah satu materi yang diberikan dalam pelatihan tersebut adalah materi protokol kesehatan yang meliputi kebersihan, kesehatan, keamanan dan keberlangsungan lingkungan dan praktek penerapannya. Peserta pelatihan sebanyak 40 orang. Metode pelatihan adalah tutorial, diskusi dan praktek. Hasil pelatihan,70\% (28 peserta) menyatakan bahwa itu adalah pelatihan pertama mereka tentang penerapan protokol kesehatan, 90\% (36 peserta) menyatakan teori tersebut dapat diterapkan di destinasi wisata di tempatnya sedangkan 10\% (4 peserta) berpendapat fasilitas pendukung masih harus dilengkapi agar kegiatan wisata dapat berjalan sesuai dengan protokol kesehatan yang ada. Sebanyak 60\% peserta (24 orang) berpendapat bahwa demi pendalaman materi tersebut maka durasi pelatihan perlu diperpanjang, sementara sebanyak 50\% peserta (20 orang) meyakini bahwa akan lebih baik apabila dalam pelatihan serupa, tenaga kesehatan ikut dihadirkan sehingga penyusunan Standar Operasional Prosedur (SOP) bagi Desa Wisata, diantaranya SOP di objek wisata dan homestay, dapat dilakukan sebagai salah satu luaran pelatihan yang dapat menjadi bekal peserta saat hendak menerapkannya di destinasinya masing-masing.
\end{abstract}

Kata kunci: Era Adaptasi Kebiasaan Baru, Pramuwisata Pedesaan, Protokol Kesehatan

\section{PENDAHULUAN}

Pramuwisata, pemandu wisata, atau dalam istilah asingnya tour guide adalah seseorang yang bertugas memberikan informasi dan memandu wisatawan di destinasi wisata yang didatangi. Seorang pemandu wisata hendaknya mampu memberikan kepuasan dengan menyuguhkan informasi yang dibutuhkan dengan jalan menyatukan pengetahuan, keterampilan, dan perasaannya selama mendampingi wisatawan (Yoeti, 2010). Karena tugasnya dalam mendampingi wisatawan di destinasi wisata, maka pemandu wisata juga seringkali menjadi representasi dari destinasi wisata yang diwakilinya. Itulah sebabnya pelayanan pemandu wisata 
juga menjadi sebuah faktor yang menentukan dalam kepuasan wisatawan sehingga hasilnya juga mempengaruhi pemasaran pariwisata destinasi tersebut (Darmawan et al., 2017; Dwipayana et al., 2017; Putra et al., 2016).

Jenis-jenis pemandu wisata berdasarkan spesifikasinya dibagi menjadi dua, yaitu pemandu wisata khusus, merupakan pemandu wisata yang bertugas khusus di salah satu atau beberapa objek wisata tertentu, dan pemandu wisata umum, merupakan pemandu wisata yang tidak bertugas pada salah satu objek wisata saja, tetapi dimana saja dia dibutuhkan (Darmawan et al., 2017). Salah satu jenis jenis pemandu wisata khusus adalah pemandu wisata pedesaan yang bertindak sebagai pemandu wisata lokal di Desa Wisata.

Desa wisata didefinisikan sebagai suatu wilayah yang menawarkan suasana asli perdesaan baik dari kehidupan sosial ekonomi, sosial budaya, adat istiadat, keseharian, arsitektur bangunan dan struktur tata ruang desa yang khas, atau kegiatan perekonomian yang unik dan menarik serta mempunyai potensi untuk dikembangkannya berbagai komponen kepariwisataan, misalnya atraksi, akomodasi, makanan-minuman dan kebutuhan wisata lainnya (Andayani et al., 2017). Dalam Desa Wisata, dilakukan pemberdayaan masyarakat yang bertujuan meningkatkan perekonomian di desa tersebut sesuai dengan program pemerintah yang tertera dalam Nawacita.

Desa Wisata sangat efektif dalam memberi peluang wirausaha sebesar-besarnya kepada masyarakat pedesaan agar dapat menikmati hasil dari kegiatan wisata yang berlangsung di daerah tersebut (Hidayat, 2019; Shoheh, 2019; Sudana, 2013). Pembangunan Desa Wisata juga sejalan dengan keberlangsungan kondisi alam, sosial, dan budaya masyarakat serta menitikberatkan pada pemanfaatan sumberdaya lokal, pencapaian kesejahteraan, dan peningkatan taraf hidup masyarakat sehingga dianggap tepat diimplementasikan di Indonesia yang begitu kaya akan sumber daya alam dan memiliki budaya yang beragam (Rusyidi \& Fedryansah, 2018; Sudana, 2013).

Pandemi Covid 19 yang cukup keras memukul sektor pariwisata tanah air sejak awal tahun 2020 ternyata berdampak pula terhadap Desa Wisata. Sebanyak 97 Desa Wisata di Indonesia merasakan efek ekonomi yang menurun karena adanya pembatalan tamu dan penutupan sementara, namun menariknya secara keseluruhan, penduduk di desa-desa tersebut masih cenderung lebih bertahan dibandingkan dengan usaha masyarakat sektor lain. Hal ini bisa jadi dikarenakan dalam Desa Wisata, penduduk tidak pernah melepaskan mata pencaharian awalnya akan tetapi membuat hal tersebut sebagai sebuah atraksi yang menjadi bagian dari daya tarik wisata yang menjual di mata wisatawan, baik mancanegara maupun domestic (Desa Wisata Institute, 2020).

Pada akhirnya setelah beberapa waktu hidup dengan Covid-19 dan menghadapi kenyataan bahwa banyak sekali sendi-sendi kehidupan masyarakat, utamanya di bidang ekonomi, yang melemah sebagai dampak dari kebijakan pembatasan sosial dan fisik berskala besar yang diterapkan pemerintah (Hanoatubun, 2020), masyarakat pariwisata mulai belajar menerima kenyataan dan berusaha bangkit dari keterpurukan dengan menggunakan keterampilannya masing-masing. Di tengah euphoria dibukanya kembali destinasi pariwisata di berbagai penjuru negeri, termasuk diantaranya Desa Wisata, protokol kesehatan tetap diberlakukan (L. Hakim, 2020).

Sebagai bentuk dari komitmen membangun Desa Wisata dan dalam rangka mempersiapkan pengelola Desa Wisata agar mampu menciptakan pariwisata yang sehat, aman dan nyaman sesuai tuntutan pasar saat ini (Pradono, 2020) maka Pemerintah Kabupaten Belitung melalui Dinas Pariwisata nya mengadakakn pelatihan bertajuk, "Pelatihan Pemandu Wisata Pedesaan" yang diadakan selama 3 (tiga) hari dan diikuti oleh 50 (lima puluh) perwakilan pemandu wisata dari pengurus Kelompok Sadar Wisata (Pokdarwis).

Belitung mulai diperhitungkan sebagai destinasi wisata saat buku dan film Laskar Pelangi meledak tahun 2010 lalu, dimana kunjungan wisatawan mulai menaik dan puncaknya pada tahun 2018 wisatawan yang datang ke Belitung mencapai angka 438 ribu wisatawan 
domestik dan mancanegara. Perkembangan pariwisata ini secara langsung lahan pekerjaan baru di sektor pariwisata di Belitung. Contohnya, para nelayan yang biasanya mencari ikan mulai menghias perahunya untuk dipakai para wisatawan yang ingin menikmati indahnya perairan Belitung (Fitriana, 2020).

Beberapa waktu ini Belitung jugasedang menunggu keputusan UNESCO yang akan menjadikan Belitung sebagai bagian dari Global Geopark. Selain keindahan alamnya, Belitung juga terkenal dengan kedai kopinya sangat mengedepankan budaya dan kekhasan Belitung baik dari segi tempat, makanan dan minuman yangditawarkan, maupun keramahtamahan dan atmosfernya (Prodjo, 2016).

Dengan meningkatnya kunjungan wisata di Kabupaten Belitung, maka meningkat pula pendapatan daerah yang jelas berpengaruh secara langsung kepada kesejahteraan masyarakatnya. Penerimaan daerah dari sektor pariwisata di Kabupaten Belitung cenderung meningkat dari tahun ke tahun. Dampak langsung terhadap Pendapatan Asli Daerah (PAD) diperoleh dari pembangunan hotel, restoran dan pengadaan transportasi. Sedangkan dampak tidak langsung diperoleh dari berbagai penerimaan pajak (hotel dan restoran) dan retribusi dari kegiatan pariwisata yang dilakukan para wisatawan. Pendapatan dari sektor pariwisata memang belum sebesar pendapatan dari sektor pertambangan yang merupakan sumber pendapatan daerah yang paling besar, namun dalam hal ini pariwisata tetap dipandang memiliki keunggulan mengingat dampak lingkungan jangka panjangnya tidak sedestruktif sector pertambangan (Harefa, 2020; Varicela, 2019).

Dalam pelatihan yang diselenggarakan di Hatika Hotel pada 24-26 Agustus 2020 ini dihadirkan Narasumber yang berasal dari beberapa pihak yang kesemuanya merupakan bagian dari Pentahelix Pariwisata, yaitu:

1. Pemerintah, dalam hal ini diwakili oleh Narasumber yang berasal dari Kementerian Pariwisata dan Ekonomi Kreatif (Kemenparekraf) yaitu Kemal Akbar, MM, yang memberikan materi mengenai perwujudan sadar wisata di era adaptasi kebiasaan baru.

2. Praktisi, dalam hal ini diwakili oleh GM Fairfield-Marriot Belitung yaitu DR. Dino Gustav Leonandri, yang memberikan materi pelayanan prima di masa adaptasi kebiasaan baru, dan

3. Akademisi yang dalam hal ini diwakili oleh Akademisi Politeknik Sahid dan Master Trainer Desa Wisata Kemenparekraf yaitu Rina Fitriana, MM yang memberikan materi mengenai penerapan protokol kesehatan di destinasi wisata.

Dalam hal ini, pentahelix pariwisata sebagai pendamping Desa Wisata memiliki peran vital sebagai fasilitator, educator, supervisor, motivator, evaluator dan komunikator (Tarunajaya, 2020).

Wirawan et al. (2016) menyatakan bahwa lebih separuh $(59,2 \%)$ pemandu wisata menyampaikan informasi risiko kesehatan yang ada di Bali, dan $76,4 \%$ menyampaikan informasi keselamatan terkait bahaya aktivitas wisata. Hasil yang lebih rendah didapatkan untuk penyampaian informasi terkait upaya pencegahan yang dilakukan, yaitu 55,6\% dan 71,6\%, masing-masing untuk pencegahan terkait risiko kesehatan dan bahaya terkait aktivitas wisata. Informasi yang paling ingin didapatkan oleh pemandu wisata secara rutin adalah penyakitpenyakit yang sedang meningkat kasusnya $(32,4 \%)$ dan risiko dari tiap aktivitas wisata $(29,6 \%)$.

Hal ini menunjukkan bahwa sebetulnya kepedulian terhadap kesehatan sudah ada, dan pemandu wisata menganggap bahwa keamanan dan keselamatan juga kesehatan wisatawan menjadi bagian dari tanggung jawab mereka selama memandu wisatawan di destinasi.Prosedur standarisasi K3 pada usaha wisata yang didirikan harus dilakukan, sehingga kecelakaan wisata pada saat dilapangan dapat diantisipasi dan ditangani dengan sigap (Mulasari et al., 2020; Rifai et al., 2020). 
Di era adaptasi kebiasaan baru ini, isu kesehatan menjadi isu utama, termasuk dalam sektor pariwisata, dimana faktor keselamatan dan protokol kesehatan di suatu destinasi wisata mempengaruhi pemilihankunjungan wisatawan (Pradono, 2020). Hal ini membuktikan persepsi wisatawan sangat besar pengaruhnya terhadap pilihan mereka akan suatu destinasi yang akan dikunjungi, terutama apabila hal tersebut menyangkut keamanan dan kesehatan selama berwisata sehingga himbauan seputar berwisata aman dan sehat, dari mulai pemakaian masker hingga perilaku sehat di destinasi, bertebaran di media sosial dan media massa (I. N. Hakim, 2020).

Di era adaptasi kebiasaan baru ini, penting bagi pemandu wisata dan unsur pelaku wisata lain di Desa Wisata untuk mengetahui apa dan bagaimana protokol kesehatan yang sesuai dengan anjuran pemerintah diterapkan di desatinasi, khususnya di Desa Wisata. Hal ini untuk menjamin tidak tersebarnya virus Covid-19 sehingga membuat kluster-kluster baru, menjamin kegiatan wisata yang sehat, aman dan nyaman serta sesuai dengan apa yang diharapkan oleh wisatawan.

Harapan wisatawan akan pelayanan prima telah bergeser dalam dunia pariwisata. Yang tadinya mengedepankan keramahan, keindahan dan kenyamanan seakrang sudah tergantikan dengan kebutuhan mereka akan kesehatan dan jaminan keamanan dari virus Covid-19 (Gelgel \& Dwijayanthi, 2020; Rachmawati \& Shishido, 2020; Romagosa, 2020).

\section{METODE}

Pemberian materi mengenai protokol kesehatan ini dilakukan secara offline selama 2 hari, yaitu tanggal 25-26 Agustus 2020 dan bertempat di Ballroom Hatika Hotel, Kecamatan Tanjung Pandan, untuk pemberian materinya dan ruang pertemuan terbuka Desa Wisata Kreatif Terong di Kecamatan Sijuk untuk pelaksanaan praktiknya. Terdapat metode yang digunakan dalam pemberian Pelatihan Protokol Kesehatan kali ini, yaitu:

1. Metode Sosialisasi: dimana pada metode ini diberikan paparan yang menggambarkan kondisi terakhir pandemic Covid-19, beberapa survey mengenai perkembangan pariwisata di masa pandemi dan dalam menyambut masa adaptasi kebiasaan baru, keinginan dan kebutuhan wisatawan mengenai pemilihan destinasi yang dikunjungi, dan bagimana seharusnya kegiatan di destinasi dilakukan sesuai dengan protokol kesehatan yang digariskan oleh kebijakan pemerintah beserta dengan contoh-contohnya, baik penerapan di homestay, atraksi, dan lain sebagainya.

2. Metode Tutorial: dimana penulis sebagai Narasumber dalam pelatihan ini memutarkan beberapa video yang memuat contoh-contoh bagaimana protokol kesehatan diterapkan di beberapa destinasi wisata, seperti di hotel, restoran, Desa Wisata, atraksi, homestay dan sebagainya, sejak saat penjemputan, saat berada di tempat-tempat tersebut, maupun pada saat mereka kembali ke tujuannya.

3. Metode Diskusi: dalam metode ini, dilakukan pemahaman dan penggalian pengalaman para peserta yang ada kaitannya dengan penerapan protokol kesehatan atau K3 selama mendampingi wisatawan di destinasi. Sekaligus untuk melihat bagaimana sebetulnya kesiapan Desa Wisata yang ada di Kabupaten Belitung untuk menerapkan protokol kesehatan, termasuk dari sisi sarana dan prasarana nya. Selama sesi ini, diketahui terdapat beberapa halangan untuk penerapan protokol kesehatan di daerah, diantaranya keengganan sebagian masyarakat untuk memakai masker, belum tersedianya tempat mencuci tangan di berbagai destinasi wisata di Belitung, dan sanksi yang kurang tegas terkait dengan aturan 3M (mencuci tangan atau menggunakan hand sanitizer, memakai masker dan menjaga jarak fisik apabila berada di tengah keramaian)

4. Metode Praktik Lapangan: dalam metode ini dilakukan in-site guiding, yaitu melakukan simulasi pemanduan dengan menggunakan protokol kesehatan. Pemanduan ini dilakukan di destinasi, baik di homestay, atraksi maupun di tempat penjemputan dan kendaraan pengangkut wisatawan. 
5. Metode Evaluasi: dimana peserta diberikan sebuah kuesioner yang berisi menganai pendapat peserta tentang materi, narasumber dan sarana prasarana pelatihan ini. Dalam metode ini pula peserta dapat memberikan masukan dansaran secara tertulis dan anonim mengenai halhal yang dirasa penting untuk ditambahkan pada materi pelatihan mengenai protokol kesehatan dan metodenya di masa yang akan datang.

\section{HASIL DAN PEMBAHASAN}

Kegiatan Pelatihan Protokol Kesehatan untuk Pemandu Wisata Pedesaan ini seluruhnya diikuti 40 (empat puluh) peserta yang berasal dari Kelompok Sadar Wisata (Pokdarwis) selaku pihak pengelola dan penanggung jawab Desa Wisata, dan pemandu wisata pedesaan yang berasal dari berbagai Desa Wisata di Kabupaten Belitung. Keseluruhan pelatihan ini memakan waktu selama 3 (tiga) hari, dimana sesi materi dan praktek guiding menggunakan protokol kesehatan di destinasi Desa Wisata terdapat di hari kedua dan hari ketiga.

Sebagai bagian dari komitmen bersama untuk menjalankan protokol kesehatan yang harus dipatuhi maka semua tahapan kegiatan dalam pelatihan ini dilakukan dengan menerapkan protokol kesehatan yang dikenal dengan $3 \mathrm{M}$ yaitu mencuci tangan, memakai masker dan menjaga jarak fisik diantara peserta selama kegiatan berlangsung. Selain itu, demi sterilnya ruangan yang dipakai untuk pemberian materi maka ruangan tersebut telah disemprot dengan desinfektan sebelum kegiatan berlangsung dan selama pelaksanaan istirahat, sholan dan makan dimana peserta dan panitia semua berada di luar ruangan.

Salah satu indikator yang dilakukan adalah pengukuran suhu tubuh peserta dan panitia sebelum dimulainya kegiatan, baik dalam kegiatan pemberian teori di dalam ruangan maupun pada saat kegiatan praktek lapangan di luar ruangan.

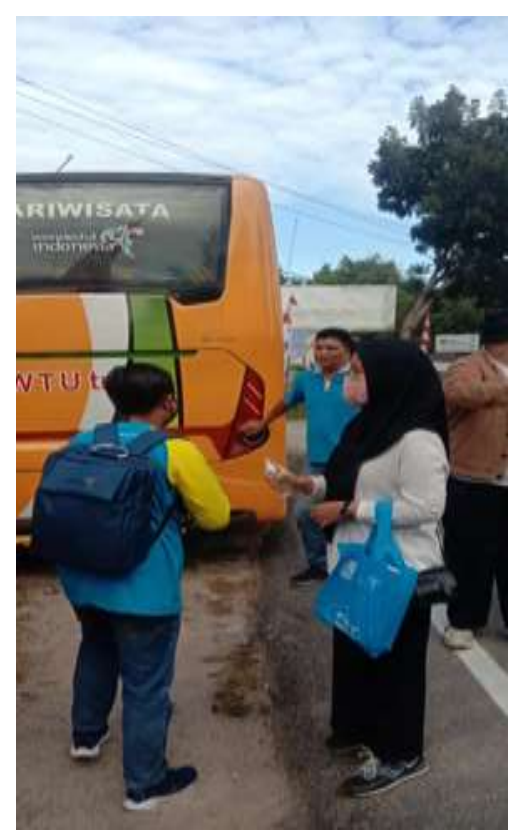

Gambar 1. Pemberian hand sanitizer sebelum menaiki bus ke tempat praktek

(Sumber: Dokumentasi panitia, 2020)

Saat semua peserta dan panitia telah dinyatakan memiliki suhu tubuh normal dan tidak mengindikasikan adanya peserta yang terkena Covid-19, maka kegiatan dapat dimulai. Dan apabila ada peserta yang terindikasi terkena Covid-19 yang ditandai dengan suhu tubuh yang tidak normal, maka akan dilakukan pemulangan agar tidak menulari peserta dan panitia serta narasumber yang terlibat dalam pelatihan kali ini. 
Pemberian materidengan metode paparan dan metode tutorial dilakukan selama 120 menit, kemudian diikuti dengan 30 menit diskusi dan berbagi pengalaman diantara para narasumber dan peserta yang terdiri dari perwakilan Kelompok Sadar Wisata (Pokdarwis) dan pemandu wisata pedesaaan yang berasal dari beberapa Desa Wisata di wilayah Kabupaten Belitung.

Selama paparan materi, terlihat bahwa sebagian peserta sebenarnya sudah pernah mendengar dan memahami apa yang dimaksud dengan protokol kesehatan, namun mereka belum pernah melakukan hal tersebut di destinasi mereka. Mereka pun mendapat gambaran mengenai penerapan protokol kesehatan di berbagai tahapan kegiatan wisata dan destinasi melalui videovideo yang diputarkan oleh para narasumber.

Pada hari selanjutnya, yaitu hari ketiga sekaligus hari terakhir pelatihan, para peserta dan panitia bersama-sama menuju Desa Wisata Kreatif Terong yang terletak di Kecamatan Sijuk dan membutuhkan waktu perjalanan sekitar 45 (empat puluh lima) menit menggunakan bus. Desa Wisata ini memiliki sungai, agrowisata buah dan sayur-mayur, pemancingan, dan lain sebagainya. Di Desa Wisata yang telah berhsil mendapatkan beberapa dana hibah CSR (Corporate Social Responsibility) ini, peserta akan diajak untuk memperaktekkan pemanduan yang sudah memakai protokol kesehatan.

Peserta kemudian dibagi ke dalam beberapa kelompok untuk bisa bekerja dengan lebih efektif dan efisien dalam menyusun protokol kesehatan sesuai dengan pembagian tugas kelompok masing-masing, yaitu di kendaraan saat penjemputan, pos masuk Desa Wisata, tempat atraksi, dan homestay Desa Wisata.

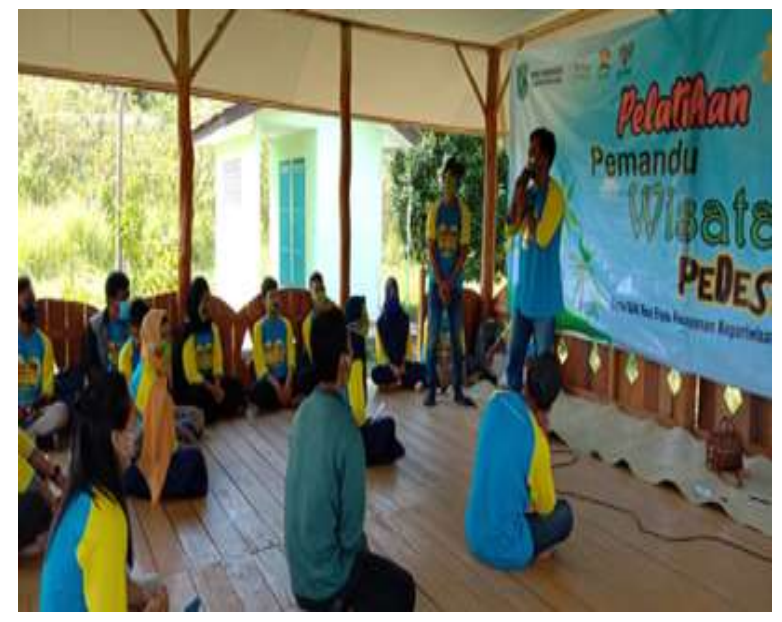

Gambar 2. Praktek/Simulasi Pemanduan

(Sumber: Dokumentasi panitia, 2020)

Setelah pemberian materi, tutorial dan diskusi serta praktek dilakukan, untuk mengukur pemahaman peserta dan demi mendapat masukan atas materi yang diberikan, maka peserta diminta untuk menjawab sebuah survey yang terdiri dari pertanyaan-pertanyaan sebagai berikut:

1. Apakah Saudara pernah mengikuti pelatihan yang berhubungan dengan protokol kesehatan di masa adaptasi kebiasaan baru. 70\% (28 peserta) menyatakan bahwa itu adalah pelatihan pertama mereka tentang penerapan protokol kesehatan, walaupun mereka (100\%) menyatakan bahwa mereka pernah mengikuti pelatihan yang serupa (pelatihan K3) di masa lalu pada saat mereka mengikuti pelatihan pemandu wisata. 


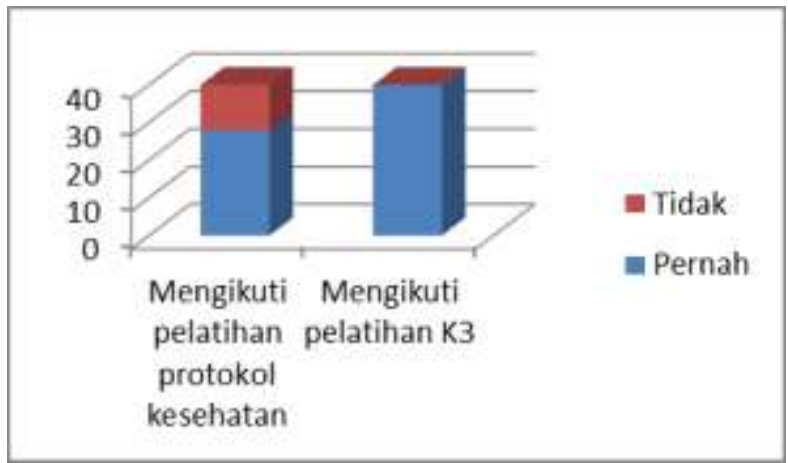

Gambar 3. Pelatihan Kesehatan (Sumber: Olah Data, 2020)

2. Menurut Saudara, dapatkah teori dan praktek mengenai protokol kesehatan yang Saudara pelajari disini diterapkan di Desa Wisata? 90\% (36 peserta) menyatakan teori tersebut dapat diterapkan di destinasi wisata di tempatnya sedangkan $10 \%$ (4 peserta) berpendapat fasilitas pendukung masih harus dilengkapi agar kegiatan wisata dapat berjalan sesuai dengan protokol kesehatan yang ada. Beberapa destinasi wisata, khususnya Desa Wisata di Kabupaten Belitung memiliki, misalnya, keterbatasan dalam hal tempat pencuci tangan, ketersediaan air bersih dan lain sebagainya.

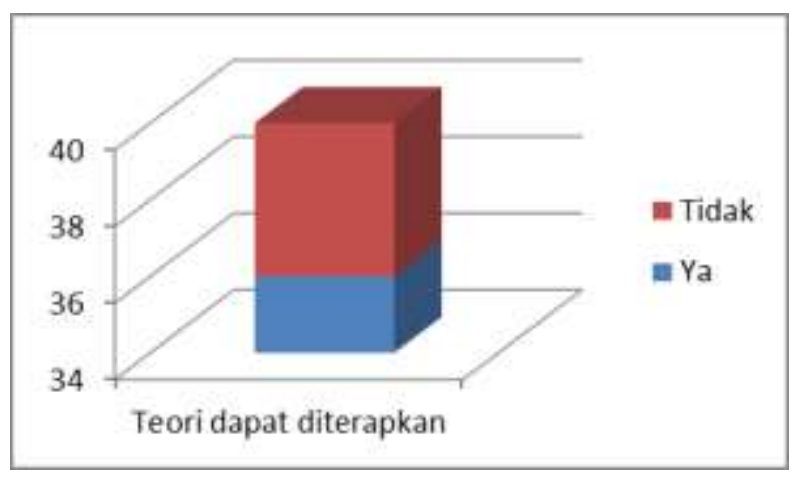

Gambar 4. Penerapan Teori (Sumber: Olah Data, 2020)

3. Menurut Saudara, bagaimana pelaksanaan pelatihan ini? Mohon berikan masukan. Sebanyak $60 \%$ peserta (24 orang) berpendapat bahwa demi pendalaman materi tersebut maka durasi pelatihan perlu diperpanjang, sementara sebanyak $50 \%$ peserta ( 20 orang) meyakini bahwa akan lebih baik apabila dalam pelatihan serupa, tenaga kesehatan ikut dihadirkan sehingga penyusunan Standar Operasional Prosedur (SOP) bagi Desa Wisata, diantaranya SOP di objek wisata dan homestay, dapat dilakukan sebagai salah satu luaran pelatihan yang dapat menjadi bekal peserta saat hendak menerapkannya di destinasinya masing-masing

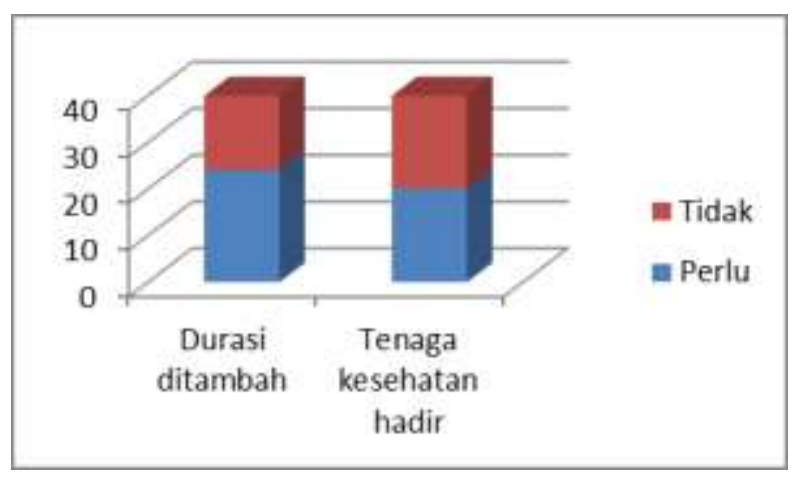

Gambar 5. Saran dan Masukan Peserta (Sumber: Olah Data, 2020) 


\section{KESIMPULAN}

Hasil dari pengabdian masyarakat kali ini, yaitu berupa pemberian materi mengenai protokol kesehatan, penyusunan protokol di Desa Wisata (baik di kendaraan, homestay maupun atraksi) dan praktek pemanduan yang sudah menerapkan protokol kesehatan. Dari survey yang dilakukan pasca pelatihan terungkap bahwa seluruh peserta menganggap materi ini menarik, kekinian, dan dibutuhkan serta mudah dipahami karena adanya praktek pemanduan yang telah menerapkan protokol kesehatan dan dilakukan di lokasi Desa Wisata (in-site guiding).

Apabila terkait dengan penerapan protokol kesehatan di desa wisata, walaupun Sebagian besar menemukan hal ini dapat dilakukan, namun terdapat sebagian peserta yang masih menganggap bahwa penerapan ini memerlukan dukungan sarana dan prasana yang di sebagian destinasi Desa Wisata masih minim, sebagai contoh keberadaan tempat cuci tangan.

Sebagai saran dan masukan dari peserta, pemaparan dan praktek untuk materi protokol kesehatan tersebut hendaknya diperpanjang dari sisi alokasi waktu dan apabila diperlukan, akan sangat baik seandainya peserta dapat langsung merasakan seperti apa kegiatan wisata yang sudah menerapkan protokol kesehatan di Desa Wisata. Selain itu, para peserta juga meyakini bahwa akan lebih baik apabila dalam pemberian teori dan pelaksanaan praktek dilengkapi dengan narasumber yang memiliki latar belakang kesehatan sehingga protokol kesehatan yang disusun menjadi lebih valid dan dapat menjadi suatu acuan bagi pelaksanaan kegiatan wisata yang sehat, aman dan nyaman di Desa Wisata masing-masing peserta.

\section{UCAPAN TERIMA KASIH}

Penulis mengucapkan terima kasih kepada Kementerian Pariwisata dan Ekonomi Kreatif Republik Indonesia dan Dinas Pariwisata kabupaten Belitung yang telah memberi dukungan financial terhadap pengabdian ini. Semoga pengabdian ini menjadi catatan amal baik kita di hadapan Tuhan Yang Maha Esa dan dapat memberikan sumbangsih bagi pembangunan SDM Pariwisata di Kabupaten Belitung. Aamiin.

\section{DAFTAR PUSTAKA}

Andayani, A. A. I., Martono, E., \& Muhamad, M. (2017). Pemberdayaan Masyarakat Melalui Pengembangan Desa Wisata Dan Implikasinya Terhadap Ketahanan Sosial Budaya Wilayah (Studi Di Desa Wisata Penglipuran Bali). Jurnal Ketahanan Nasional, 23(1), 1. https://doi.org/10.22146/jkn.18006

Darmawan, I. P. E., Negara, I. M. K., \& Sudana, I. P. (2017). Pengaruh pelayanan pramuwisata lokal terhadap citra daya tarik wisata besakih. Jurnal Analisis Pariwisata, 17(2), 93-97.

Desa Wisata Institute. (2020). Survey Desa Wisata Institute. (2020). Dampak Pandemi Covie-19 terhadap Desa/Kampung Wisata di Indonesia. https://desawisatainstitute.com/riset

Dwipayana, I. K., Widana, I. K. A., \& Sutarya, I. G. (2017). Analisis faktor penentu kepuasan wisatawan perancis terhadap kualitas pelayanan pramuwisata di pt. pacto bali prima holidays sanur bali. Jurnal Penelitian Agama Hindu, 1(1), 100-104.

Fitriana, R. (2020). Meningkatkan Keterampilan Pelajar Melalui Pelatihan Grooming Dalam Tourism Goes To School. Jurnal Masyarakat Mandiri, 4(2), 173. https://doi.org/https://doi.org/10.31764/jmm.v4i2.1946

Gelgel, I. P., \& Dwijayanthi, N. M. A. (Eds.). (2020). Bali vs covid 19: book chapters. Nilacakra.

Hakim, I. N. (2020). Wabah dan Peringatan Perjalanan dalam Persepsi Wisatawan. JUMPA, 7(1), 31-51.

Hakim, L. (2020). COVID-19 and the Moment to Evaluate Tourism Euphoria , Indonesia. Journal of Indonesian Tourism and Development Studies, 8(2), 119-123. https://doi.org/10.21776/ub.jitode.2020.008.02.09

Hanoatubun, S. (2020). Dampak covid-19 terhadap perekonomian indonesia. EduPsyCouns 
Journal, 2(1), 146-153.

Harefa, M. (2020). Dampak sektor pariwisata terhadap penerimaan daerah di kabupaten belitung. Jurnal Ekonomi Dan Kebijakan Publik, 11(1), 65-77.

Hidayat, N. (2019). Upaya peningkatan kesejahteraan sosial masyarakat melalui pengembangan desa wisata (studi kasus di desa jetis, kecamatan nusawungu, kabupaten cilacap) (skripsi). IAIN Purwekorto.

Mulasari, S. A., Izza, A. N., Masruddin, Hidayatullah, F., A., F. D. P. B. M., \& Astry, A. (2020). Pelatihan kesehatan dan keselamatan kerja ( $\mathrm{k} 3$ ), service excellent, serta pengelolaan sanitasi lingkungan tempat wisata Desa. Jurnal Pemberdayaan: Publikasi Hasil Pengabdian Kepada Masyarakat, 4(1), 61-66.

Pradono, M. N. (2020). Kampanye Protokol CHS di Destinasi Wisata Perlu Strategi Khusus. https://ekonomi.bisnis.com/read/20200707/12/1262502/kampanye-protokol-chs-didestinasi-wisata-perlu-strategi-khusus

Prodjo, W. A. (2016). Doyan kopi? kunjungi 2 warkop legendaris di belitung. https://travel.kompas.com/read/2016/03/16/160300027/Doyan.Kopi.Kunjungi.2.Warkop

Putra, I. G. G. L. W., Sudana, I. P., \& Mahadewi, N. P. E. (2016). Analisis Kualitas Pelayanan Pramuwisata Terhadap Kepuasan Wisatawan Di Pt. Bali Sun Tours. Jurnal IPTA, 4(2), 58-63. https://doi.org/10.24843/ipta.2016.v04.i02.p12

Rachmawati, I., \& Shishido, K. (2020). Travelers' motivations to travel abroad during covid 19 outbreak. International Journal of Applied Sciences in Tourism and Events, 4(1), 1. https://doi.org/10.31940/ijaste.v4i1.1772

Rifai, M., Agustin, H., \& Isni, K. (2020). Pencegahan risiko kesehatan dan keselamatan berwisata: studi kasus objek wisata lava bantal-sleman , daerah istimewa yogyakarta. PROMOTIF: Jurnal Kesehatan Masyarakat, 10(1), 1-7.

Romagosa, F. (2020). The COVID-19 crisis: Opportunities for sustainable and proximity tourism. Tourism Geographies, 22(3), 1-5. https://doi.org/10.1080/14616688.2020.1763447

Rusyidi, B., \& Fedryansah, M. (2018). Pengembangan Pariwisata Berbasis Masyarakat. Jurnal Pekerjaan Sosial, 1(3), 155-165. https://doi.org/10.24843/jdepar.2017.v05.i01.p26

Shoheh, M. M. (2019). Pemberdayaan pemandu wisata (Tour Guide) Desa Agrowisata Lebakmuncang dalam meningkatkan kesejahteraan ekonomi masyarakat (skripsi). UIN Sunan Gunung Djati.

Sudana, I. P. (2013). Strategi Pengembangan Desa Wisata Ekologis di Desa Belimbing, Kecamatan Pupuan Kabupaten Tabanan. Analisis Pariwisata, 13(1), 11-31.

Tarunajaya, W. B. (2020). Buku Panduan Pemberdayaan Masyarakat Desa Wisata Berbasis Pendampingan (Kerjasama Kemenparekraf, Kemendes PDTT dan Perguruan Tinggi). Direktorat Pengembangan SDM Pariwisata Kementerian Pariwisata dan Ekonomi Kreatif/Badan Pariwisata dan Ekonomi Kreatif.

Varicela, N. (2019). Perbandingan peran pendapatan asli daerah sektor pertambangan dan sektor pariwisata dalam meningkatkan perekonomian Provinsi Kepulauan Bangka Belitung (skripsi). Universitas Bangka Belitung.

Wirawan, I. M. A., Wirawan, D. N., \& Kurniasari, N. M. D. (2016). Praktik pemberian informasi kesehatan wisata oleh pramuwisata di bali.

Yoeti, O. A. (2010). Dasar-dasar pengertian hospitality \& pariwisata. Alumni. 